\title{
Estudio experimental de la fisuración de la fábrica de ladrillo bajo solicitaciones de tracción y cortante en modelos reducidos
}

\section{Experimental scale model study of cracking in brick masonry under tensile and shear stress}

\author{
E. Reyes Pozo(*), M. J. Casati Calzada(**) y L. C. Gálvez Ruiz(*)
}

Recepción/Received: 26-IX-06

Aceptación/Accepted: 11-1-07

Publicado online/Online publishing: 20-VI-08

\section{RESUMEN}

Este artículo presenta los resultados de la investigación realizada sobre el comportamiento en rotura de la fábrica de ladrillo bajo solicitaciones de tracción y cortante. La investigación está encaminada a proporcionar modelos de ensayo y resultados experimentales que permitan conocer mejor los procesos de agrietamiento de la fábrica de ladrillo bajo tensiones normales de tracción y tangenciales. Se presentan los resultados de una campaña experimental desarrollada con dos tipos de probeta: 1) la probeta compacta con doble entalla solicitada a compresión asimétrica, y 2) la probeta de flexión con entalla solicitada bajo carga asimétrica aplicada en tres puntos. Se han ensayado probetas de dos tamaños semejantes (razón de semejanza 2) y varias orientaciones de los tendeles, con el fin de ver cómo afecta la orientación de los tendeles en la propagación de las grietas. Los ensayos se han realizado con probetas a escala $1 / 4$ de un muro de fábrica de ladrillo de una hoja a soga de medio pie de espesor.

Palabras clave: fábrica de ladrillo, propiedades mecánicas, fisuración, tracción, cortante.

\section{SUMMARY}

This article discusses the results of research conducted on the failure behaviour of brick masonry under tensile and shear stress. The study was designed to develop test models and generate experimental results able to provide greater insight into tensile and shear stresses cracking in brick masonry. The results of a campaign conducted with two types of specimens are discussed: 1) double-edge notched specimens under non-symmetrical compression stress, and 2) three point bending specimens under nonsymmetrical loading. Tests were run on specimens of similar size (similarity rate 2) and different bed joint orientation to determine how bed joint orientation affects crack propagation. The tests were conducted on scale models (1/4) of a single wythe, stretcher bond brickwork masonry wall one half foot thick.

Keywords: brick masonry, mechanical properties, cracking, tensile stress, shear.

(*) Universidad Politécnica de Madrid, E.T.S.I. Caminos, Canales y Puertos, (Madrid, España).

(**) Universidad Politécnica de Madrid, E.U.I.T. Aeronáuticos, (Madrid, España). El error en la filiación de MJ CC en la edición impresa se corrige en esta edición electrónica. 


\section{INTRODUCCIÓN}

La fábrica de ladrillo es un material compuesto formado por la disposición ordenada, según el tipo de aparejo, de ladrillos unidos por un mortero. En España la industria cerámica tiene una larga tradición y este material se emplea en la construcción desde hace siglos. En la actualidad su uso en edificación es muy frecuente para la construcción de elementos de cierre y divisorios, sobre todo en edificios de mediana altura (1). De esta forma la función habitual de la fábrica de ladrillo se reduce a simples elementos separadores o de cierre, mientras que su uso como elemento estructural, aprovechando su capacidad resistente, es mucho más limitado (1). Este aspecto justifica que los estudios sobre la rotura de la fábrica sean escasos y el conocimiento sobre sus mecanismos de rotura menor que en otros materiales de construcción como el hormigón o el acero. Sin embargo, una mayor calidad en la edificación exige evitar el agrietamiento de muros y elementos de cierre, lo que debe plantearse a partir de un mejor conocimiento de la fisuración de la fábrica de ladriIlo. Además, este material constituye un tipo de construcción en expansión incorporando nuevas formas, fruto de la innovación reciente. Las mejoras técnicas introducidas en estos elementos constructivos hacen que el uso de la fábrica, en la actualidad, pueda ser muy interesante como material de construcción de altas prestaciones.

Entre las características mecánicas más determinantes de las construcciones de ladrillo destacamos su baja resistencia a tracción, junto con su alta rigidez en comparación con los elementos estructurales que rodean a la fábrica en el seno de la estructura, como pueden ser forjados, vigas o cimentaciones. Precisamente la escasa capacidad de la obra de fábrica para acompañar a estos elementos estructurales en sus movimientos durante su vida de servicio, hace que la fábrica de ladrillo sea un elemento que con frecuencia presente fisuras debido, por ejemplo, a asientos diferenciales o a deformaciones diferidas de forjados. Como se puede apreciar en las Figuras 1 y 2 lo común en este tipo de fallo es la formación de una o un número discreto de fisuras de un tamaño considerable, característico de la rotura por solicitaciones de tracción y cortante, y no la existencia de gran cantidad de microfisuras. Dependiendo de las condiciones de contorno de cada caso el agrietamiento ocurre separando hiladas, o bien rompiendo ladrillos y mortero con distinto ángulo de inclinación.

Hasta ahora el estudio de los mecanismos de fallo de la fábrica de ladrillo se ha centrado fundamentalmente en las solicitaciones de compresión y compresión/cortante (2-6), habiéndose estudiado poco el fallo bajo solicitaciones de tracción y cortante $(1,7-9)$. Actualmente no se dispone de ensayos, ni tampoco de suficientes datos

\section{INTRODUCTION}

Brickwork masonry is a composite material consisting in the orderly arrangement of bricks set in mortar following a given bond pattern. Spain has long had a strong claybased materials industry and bricks have been used in construction for centuries. Today masonry is commonly used to build outer walls and partitions, particularly in medium height buildings (1). In standard construction, then, brick masonry is essentially deployed to enclose and separate, whereas advantage is seldom taken of its bearing capacity to build structural elements (1). This would explain the paucity of studies on masonry failure and the narrower understanding of its failure mechanisms than for other building materials such as concrete or steel. Nonetheless, in higher quality construction cracking in walls and enclosures must be prevented, necessitating a fuller knowledge of this process. Moreover, this type of construction is continually expanding and adopting new forms as a result of recent innovations. Improved techniques in such building elements are making masonry a high performance construction material of specific interest.

The key mechanical characteristics of brick construction include low tensile strength and high stiffness compared to the surrounding structural members, such as floor/ceiling slabs, beams or foundations. The scant capacity of masonry to accommodate the movements taking place in structural members throughout their service life is what makes brick masonry crack due, for instance, to differential settling or deferred slab deformation. As Figures 1 and 2 show, this type of failure normally entails the formation of one or several sizeable cracks, characteristic of tensile and shear stress failure, rather than a large number of micro-cracks. Depending on the boundary conditions prevailing in each case, cracks may separate courses of bricks, or run across bricks and mortar at different slant angles.

To date, the study of failure mechanisms in brickwork masonry has focused primarily on compression and compression / shear stress (2-6), whereas tensile and shear stress failure has been explored less extensively. At this time, neither the tests nor the experimental data at hand suffice to assess brick masonry behaviour under this 


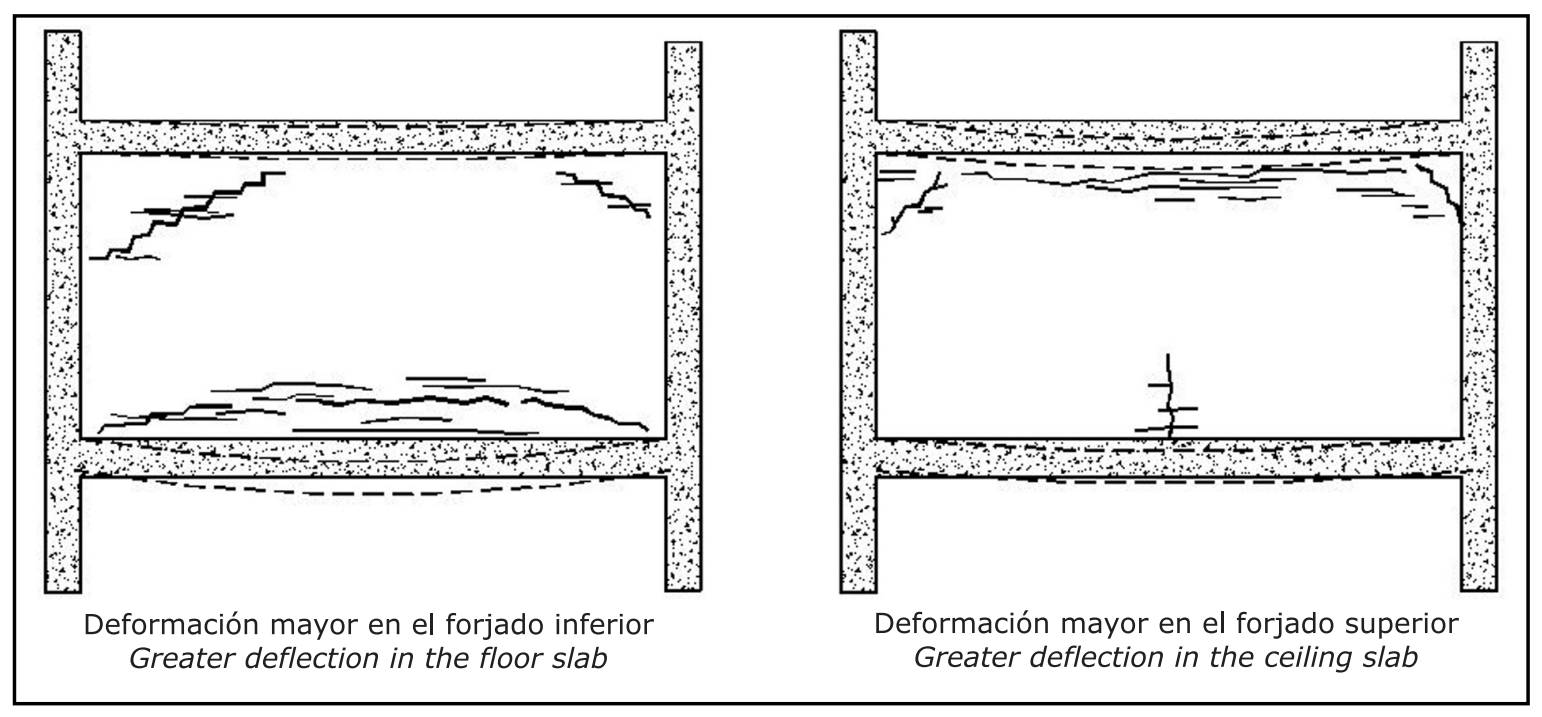

Figura 1. Fisuración inducida por la excesiva flexibilidad del forjado.

Figure 1. Cracking induced by excessive slab flexibility.

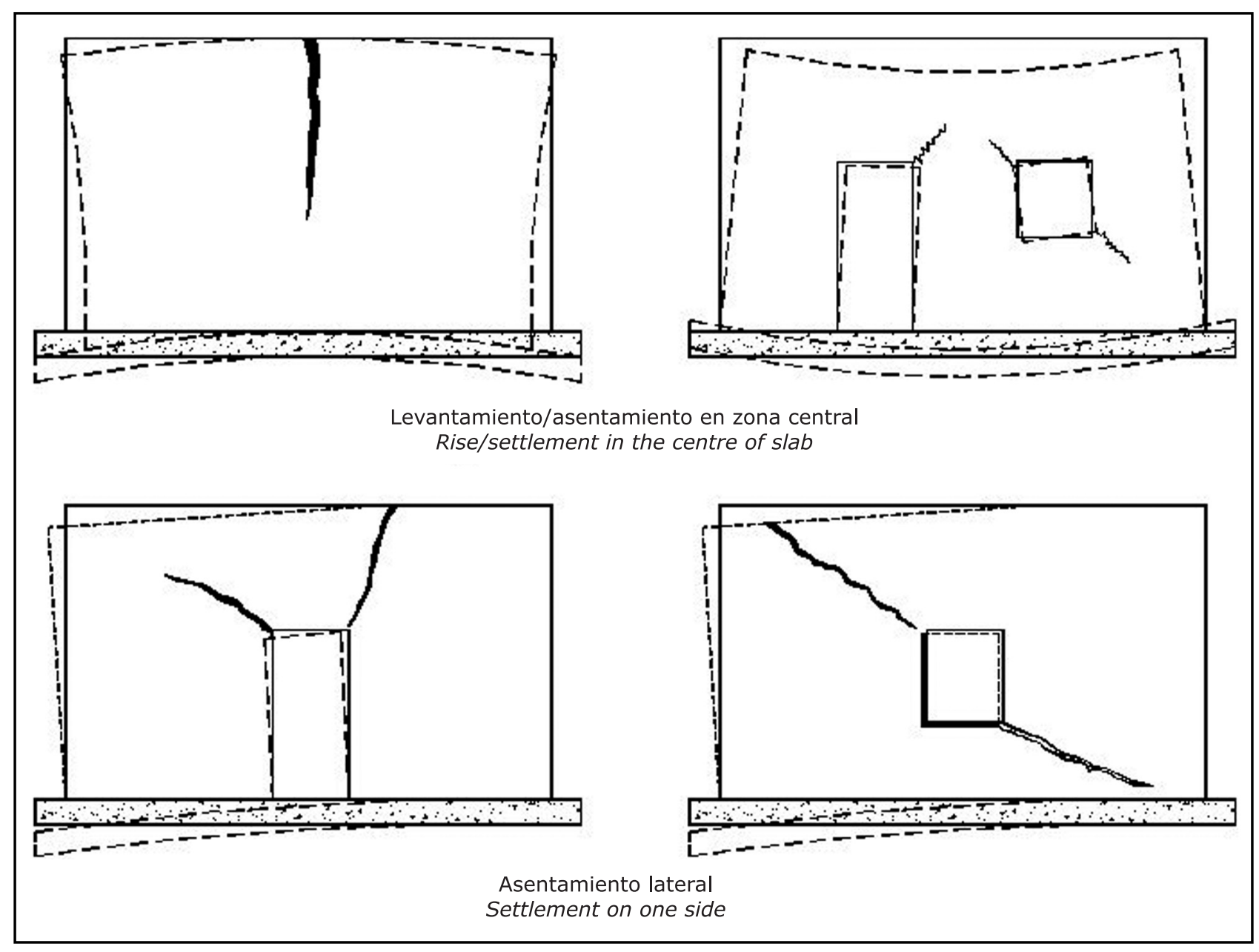

Figura 2. Fisuración inducida por un asiento diferencial.

Figure 2. Cracking induced by differential settling. 
experimentales, para evaluar el comportamiento de la fábrica de ladrillo frente a esta combinación de esfuerzos. Este artículo propone dos ensayos para proporcionar resultados de la propagación de grietas en probetas de fábrica de ladrillo, así como los resultados de la campaña experimental realizada. Con este objetivo se han adaptado para este material dos tipos de probeta que ya habían sido empleados con éxito por los autores en el estudio de la fractura por tracción y cortante de hormigones y morteros (10-11): 1) la probeta compacta con doble entalla (PCDE) solicitada a compresión asimétrica, y 2) la probeta de flexión con entalla solicitada con carga asimétrica aplicada en tres puntos.

En el estudio del comportamiento mecánico de la fábrica de ladrillo, y especialmente de su rotura, es importante tener presente que se trata de un material compuesto. Normalmente los ladrillos y el mortero, así como la intercara entre ambos, se disponen formando hiladas. Como consecuencia, las propiedades mecánicas y resistentes del material resultante dependerán fuertemente, además de las de sus materiales constituyentes, de la dirección que se someta a estudio, influyendo en la dirección de crecimiento de las grietas $(2,12,13)$, ya que a priori las juntas entre ladrillo y mortero pueden ser consideradas como planos de debilidad. En la práctica las grietas crecen formando ángulos diversos con relación a los tendeles. Así, en la Figura 1 se muestra un caso en el que la fisuración principal se produce siguiendo una trayectoria sensiblemente horizontal a través de la junta horizontal (tendel). En las Figuras 2.b, 2.c y 2.d se observa cómo a partir de la esquina de un hueco en la estructura, puerta o ventana, se producen fisuras que avanzan formando un ángulo próximo a 45 grados con la dirección de las hiladas. Como último ejemplo, las Figuras 1.b y 2.a muestran dos casos en los que el agrietamiento es vertical, formando 90 grados con los tendeles, atravesando ladrillos y juntas verticales (llagas).

\section{MÉTODO EXPERIMENTAL DE ENSAYO}

Como ya se ha comentado no existen ensayos sobre fábricas de ladrillo que reproduzcan el comportamiento bajo solicitaciones de tracción y cortante. Por lo que el objeto de la campaña experimental fue conseguir estos resultados experimentales. Con este fin se diseñó un programa de ensayos sobre probetas de fábrica de ladrillo a escala $1 / 4$ de la fábrica real. El empleo de probetas a escala tuvo como objetivo poder utilizar una máquina universal de ensayos hidráulica servocontrolada. Una máquina de estas características aporta indudables ventajas, entre las que cabe destacar la velocidad de respuesta, disponer de unas condiciones de apoyo muy claras y usar una instrumentación de alta precisión. combination of forces. The present article proposes two tests to study cracking in brick masonry specimens and discusses the results gathered during the experimental campaign conducted. Two types of specimens successfully used by the authors in tensile and shear stress studies on concrete and mortar (10-11) were adapted for this purpose: 1) double-edge notched specimens (DENTC) under non-symmetrical compression stress, and 2) three point bending specimens under non-symmetrical loading.

Any study of the mechanical behaviour of brickwork masonry, and particularly failure studies, must give due consideration to its composite nature. Normally bricks and mortar and the interface between the two are arranged to form rows. Consequently, the mechanical properties and strength of the resulting material are heavily dependent upon not only the constituent materials, but also the direction tested. The latter affects the direction of crack growth $(2,12,13)$, for the interface between the brick and mortar can be regarded, a priori, to constitute a plane of weakness. In practice cracks grow forming different angles with the bed joints. Figure 1, for instance, illustrates a case in which the main crack follows a perceptibly horizontal path along the bed (horizontal) joint. Figures 2.b, 2.c and 2.d show how cracks grow from a corner of an opening in the structure, such as a window or door, at an angle of approximately 45 degrees with respect to the courses of brick. In one last example, found in Figures 1.b and 2.a, cracking is vertical in two cases, forming 90-degree angles with the bed joints and crossing bricks and running along head joints.

\section{TEST METHOD}

Given the afore-mentioned absence of tests to reproduce brick masonry behaviour under tensile and shear stresses, the present experimental campaign aimed to obtain such experimental results. To this end, a test programme was designed for scale model brick masonry specimens, one fourth the size of the actual wall. The reason for working with scale models was to be able use a universal electro-hydraulic servo-controlled load frame. Facilities of these characteristics have indisputable advantages, most prominently response time, existence of clearly defined boundary conditions and high precision instrumentation. 
Para poder estudiar la distinta casuística encontrada en la práctica en la fisuración de tabiques y muros de ladrillo solicitados a tracción y cortante, la campaña experimental se diseñó barriendo varios ángulos entre la dirección de las hiladas de material y la de solicitación. Las probetas PCDE se ensayaron con tres orientaciones de las hiladas ( 0,90 y 45 grados), y las probetas de flexión en tres puntos se ensayaron con dos tamaños semejantes con razón de similitud 2 y varias orientaciones de los tendeles $(0, \pm 30, \pm 45, \pm 60$ y 90 grados), todos los ángulos respecto al plano de aplicación de la carga.

\subsection{Confección de las probetas}

El primer paso para hacer las probetas fue la confección de paneles de fábrica de ladrillo, reproduciendo a escala $1 / 4$ un muro de ladrillo a soga de medio pie de espesor, con tres orientaciones de los tendeles $(0,45$ y 90 grados) y dos tamaños semejantes de dimensiones $675 \times 150 \times$ $26,5 \mathrm{~mm}^{3}$ y $337,5 \times 75 \times 26,5 \mathrm{~mm}^{3}$. Posteriormente de las probetas mayores rotas a flexión en tres puntos se obtuvieron probetas pequeñas $\left(337,5 \times 75 \times 26,5 \mathrm{~mm}^{3}\right)$ con los tendeles a \pm 30 y \pm 60 grados. Los ladrillos a escala se obtuvieron a partir de ladrillos macizos comerciales cerámicos de arcilla silícea, cortados con sierra circular de diamante por vía húmeda. Las dimensiones de las piezas de ladrillo a escala $1 / 4$ fueron $48 \times 26.5 \times 10$ $\mathrm{mm}^{3}$, siendo paralelepípedos de caras planas y bien acabadas. Como ligante se utilizó un micro-mortero. Este micro-mortero se componía de un cemento Portland 42,5 y un árido compuesto por arena natural silícea de tamaño máximo $1 \mathrm{~mm}$, adoptando la escala $1 / 4$ tanto para la granulometría como para el tamaño. El espesor de la juntas de mortero fue $3 \mathrm{~mm}$. Para mejorar las características mecánicas del mortero y garantizar el mismo comportamiento de la intercara que en la fábrica real, se añadió humo de sílice (13\% del peso de cemento) y para garantizar la penetración del mortero entre las juntas se añadió superfluidificante $(3 \%$ del peso de cemento y humo de sílice). Las probetas se fabricaron, en posición horizontal, en moldes prismáticos de acero, con las caras interiores rectificadas. Algunas fotos de los ensayos de las probetas de fábrica a escala parecen mostrar un acabado imperfecto de los ladrillos a escala, sin embargo no es así sino que al confeccionarlas en posición horizontal la lechada manchó superficialmente el ladrillo al penetrar entre el ladrillo y el molde metálico, dando ese aspecto superficial.

Los paneles de fábrica se ensayaron para obtener las propiedades mecánicas de la fábrica siguiendo el ensayo que recomienda la RILEM (50-FMC) (14) para la medida de la energía de fractura $\left(G_{F}\right)$. De forma indirecta se obtuvieron también los valores del modulo de deformación longitudinal $(E)$ y la resistencia a tracción $\left(\mathrm{f}_{\mathrm{t}}\right)$. Además, con el mismo método de ensayo se obtuvieron las propieda-
The experimental campaign was designed to span a range of angles between the directions of the courses of bricks and the stress, to study the different circumstances found in practice in brick partition and wall cracking. The CDNS specimens were tested for three course orientations (0, 90 and 45 degrees), while two similar sizes (similarity ratio 2) of specimens were subject to a threepoint bending test, likewise with several bed joint orientations $(0, \pm 30, \pm 45, \pm 60$ and 90 degrees). All angles were measured with respect to the loading plane.

\subsection{Specimen preparation}

The first step in preparing the specimens was to build two similarly sized $\left(675 \times 150 \times 26.5 \mathrm{~mm}^{3}\right.$ and $337.5 \times 75$ $\left.x 26.5 \mathrm{~mm}^{3}\right)$ brick masonry panels, reproducing a halffoot brick wall with a stretcher bond on a scale of (1/4), with three bed joint orientations (0, 45 and 90 degrees). After the three-point bending test, smaller specimens $\left(337.5 \times 75 \times 26.5 \mathrm{~mm}^{3}\right)$ with bed joints at \pm 30 and \pm 60 degrees were obtained from the fragments of the larger specimens. Commercial solid siliceous clay bricks were wet cut to a scale of 1/4 with a diamond blade circular saw. These bricks were parallelepipeds with flat, wellfinished sides measuring $48 \times 26.5 \times 10 \mathrm{~mm}^{3}$. The binder used was a micro-mortar consisting in a 42.5 Portland cement and natural siliceous aggregate with a maximum size of $1 \mathrm{~mm}$. The scale for both the particle size distribution and the size was 1/4. Mortar joints were $3 \mathrm{~mm}$ thick. Silica fume (13\% by cement weight) was added to improve the mechanical characteristics of the mortar and guarantee the same behaviour at the interface as in real masonry. Similarly, a superplasticizer (3\% by weight of cement plus silica fume) was included to guarantee mortar penetration at the joints. The specimens were built horizontally in steel prismatic moulds with ground interiors. Although in some of the photographs of the masonry specimens, the finish on the bricks cut to scale appears to show imperfections, these were actually due to surface stains from the grout that leaked between the brick and the steel mould due to the horizontal position in which the specimens were built.

The masonry panels were tested as described in RILEM (50-FMC) (14) guidelines on the determination of failure energy $\left(G_{F}\right)$. Young's modulus $(E)$ and tensile strength $\left(f_{t}\right)$ were also determined, indirectly. Moreover, the same test method was used to obtain the properties of the 
des de los componentes de la fábrica: el mortero, el ladrillo, y la intercara ladrillo-mortero. Las Tablas 1 y 2 recogen estos valores.

Tabla 1 / Table 1

Propiedades mecánicas de la fábrica Brick masonry. Mechanical properties

\begin{tabular}{|c|c|c|c|}
\hline $\begin{array}{c}\text { Orientación } \\
\text { Orientation }\end{array}$ & $\boldsymbol{G}_{\boldsymbol{F}} \mathbf{( N / \mathbf { m } )}$ & $\boldsymbol{f}_{\boldsymbol{t}} \mathbf{( M P a )}$ & $\boldsymbol{E}(\mathbf{G P a})$ \\
\hline horizontal & 75 & 5.8 & 38 \\
\hline $45 \stackrel{\circ}{54}$ & 4.1 & 28 \\
\hline vertical & 33 & 2.4 & 18 \\
\hline
\end{tabular}

$G_{F}$ : energía de fractura / specific fracture energy

$f_{t}$ : resistencia a tracción / tensile strength

E: módulo de elasticidad / Young's modulus

La Figura 3 muestra la geometría y dimensiones de los dos tipos de probetas. Para obtener las probetas PCDE, las dos mitades de las probetas de fábrica resultantes del ensayo de fractura fueron cortadas con sierra circular de diamante a baja velocidad. De la misma forma se les practicó las dos entallas. Como muestra la Figura 3.b, las dimensiones del segundo tipo de probetas coinciden con los paneles confeccionados, siendo únicamente necesario cortar la entalla. Las entallas se practicaron acabando dentro de un ladrillo para no favorecer ninguna dirección en el inicio de la fisuración. specimen components: mortar, brick and brick-mortar interface. These values are given in Tables 1 and 2 .

Tabla 2 / Table 2

Propiedades mecánicas de los materiales que constituyen la fábrica Mechanical properties of the constituent elements of brick masonry

\begin{tabular}{|c|c|c|}
\hline Elemento / Element & $\boldsymbol{G}_{\boldsymbol{F}}(\mathbf{N} / \mathbf{m})$ & $\boldsymbol{f}_{\mathbf{t}} \mathbf{( M P a )}$ \\
\hline Ladrillo / Brick & 107 & 7.6 \\
\hline Mortero / Mortar & 86 & 7.6 \\
\hline Intercara / Interface & 10 & - \\
\hline
\end{tabular}

$G_{F}$ : energía de fractura / specific fracture energy $f_{t}$ : resistencia a tracción / tensile strength

Figure 3 shows the geometry and dimensions of the two types of specimens. The DENTC specimens were obtained by cutting the two halves of the specimens generated by the bending test with a diamond circular saw at a low speed. The same procedure was used to notch the specimens. As Figure 3.b shows, the dimensions of the second type of specimens concurred with the size of the panels prepared. Notches were made in the brick so as not to favour the initiation of cracking in any particular direction.

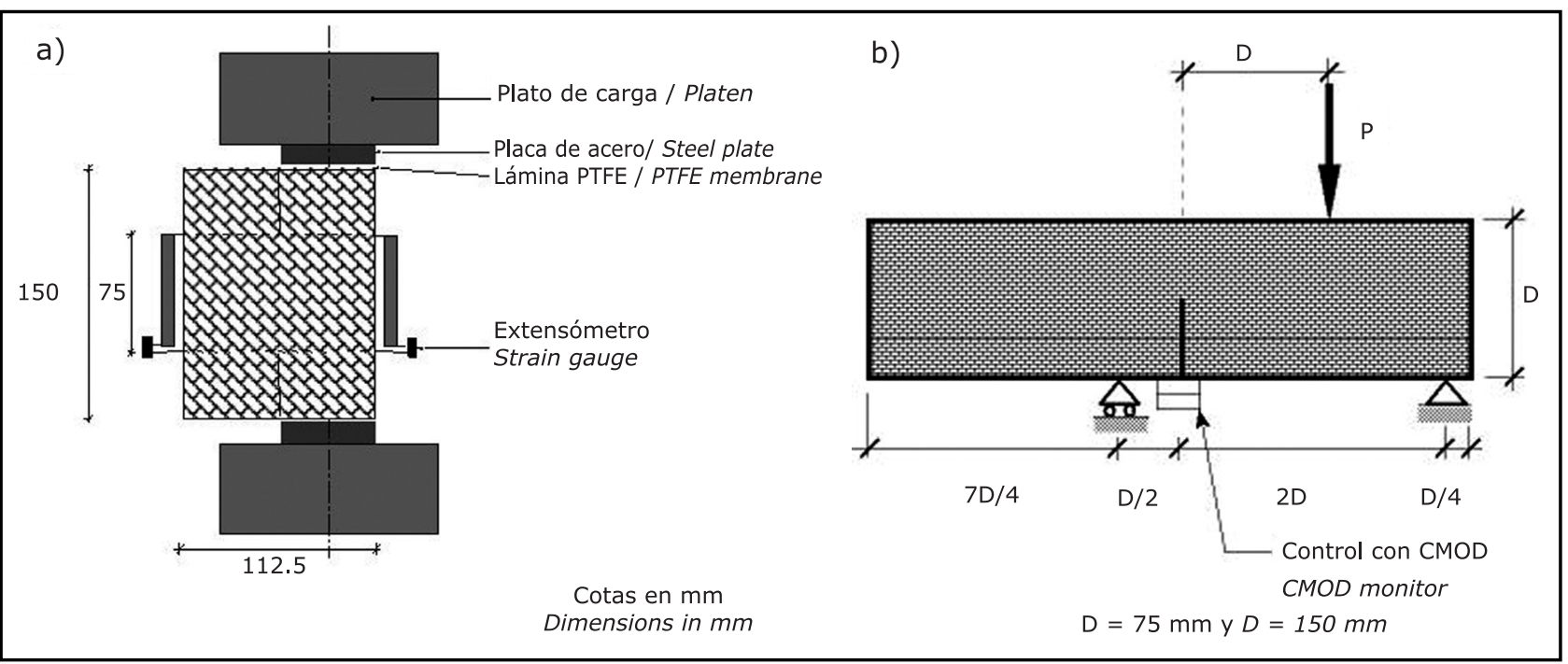

Figura 3. Esquema, dimensiones de la probeta y dispositivo de ensayo:

a) compacta con doble entalla (PCDE), y b) probeta de flexión en tres puntos.

Figure 3. Specimen dimensions and test set-up:

a) compact double-notched specimen (CDNS) and b) three-point bending specimen. 


\subsection{Descripción de los ensayos}

\subsubsection{Probetas con doble entalla}

Los ensayos se realizaron con una máquina hidráulica servocontrolada (INSTRON, 8805) de 1000 kN de capacidad. Este ensayo consistió en aplicar una carga de compresión sobre una de las dos mitades de las probetas con doble entalla (ver Figuras 3 y 4). Entre los platos de la máquina y las caras superior e inferior de la probeta se colocaron dos placas de acero rectificado, para asegurar un adecuado reparto de la carga. Además, para eliminar el rozamiento entre la placa de acero y la fábrica de ladrillo se insertó una lámina de Politetrafluoruro-etileno (PTFE), como muestran las Figuras 3 y 4 . Este procedimiento de ensayo ha sido utilizado con éxito para el estudio de la fractura de hormigón bajo solicitaciones de tracción y cortante (10). Se realizaron 9 ensayos, tres probetas por cada orientación de los tendeles.

\subsection{Tests}

\subsubsection{Double-edge notched specimens}

The tests were conducted on an INSTRON 8805 1000-kN hydraulic servo-controlled load frame. The test consisted in applying compression force to one of the two halves of the double-edge notched specimens (see Figures 3 and 4). Two ground steel laminates were positioned between the tester plates and the top and bottom of the specimen to ensure proper load distribution. In addition, a polytetrafluoride-ethylene (PTFE) membrane was placed between the steel laminate and the brick masonry to prevent friction, as shown in Figures 3 and 4. This test procedure has been successfully used to study tensile and shear stresses mediated concrete failure (10). Nine tests were run, three specimens per bed joint orientation.

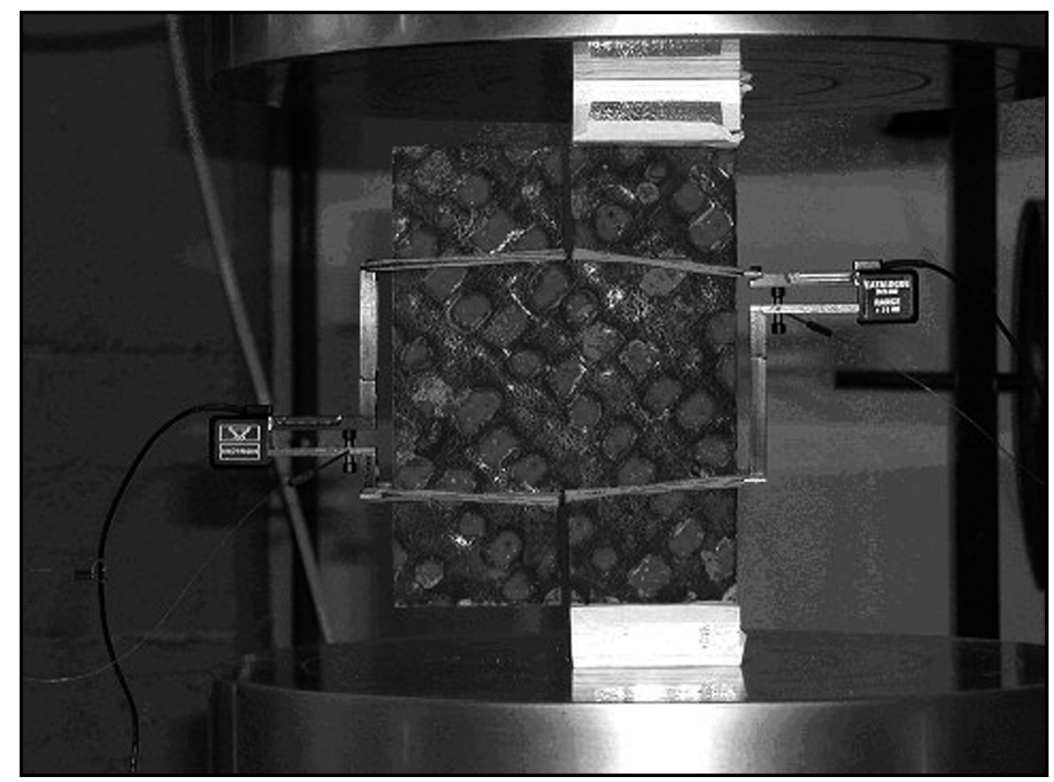

Figura 4. Probeta compacta de doble entalla, con los tendeles a 45으, durante un ensayo. Figure 4. Compact double-notched specimen with 45-degree bed joints.

Durante los ensayos se registraron los siguientes parámetros: la carga, el desplazamiento del actuador, el tiempo transcurrido y el desplazamiento en los puntos situados a la altura de la punta de las entallas sobre las caras verticales de las partes cargadas y no cargadas de la probeta, ver Figuras 3 y 4 .

Un aspecto muy importante de este procedimiento de ensayo fue distinguir entre las fisuras generadas por las tensiones de tracción y cortante en el ligamento, de aquellas producidas por el fallo por compresión. Como es sabido, cuando en una fábrica una fisura puede detectar-
The following parameters were recorded during the tests: load, displacement of the actuator, time elapsing and displacement of the points aligned with the tip of the notches on the vertical sides of the loaded and unloaded parts of the specimen, see Figures 3 and 4.

One very important aspect of this test procedure was to distinguish between cracks generated in the masonry by tensile and shear stress from those caused by compression failure. By the time a crack in masonry can be detected by the naked eye, it is generally regarded to be highly 
se a simple vista, esta fisura ya tiene un desarrollo importante. Para poder observar la fisuración desde el principio, no detectable a primera vista, se adoptaron dos técnicas: a) recubrir las caras de la probeta con una fina capa de fluoresceína (este producto cambia de color cuando la fisura se empieza a abrir y el agua contenida en el interior de la probeta sale fuera), b) observar la punta de la entalla con un microscopio óptico después del ensayo.

\subsubsection{Probetas de flexión en tres puntos}

Este segundo tipo de ensayo se llevó a cabo con la misma máquina de ensayos con un dispositivo de flexión. Para conseguir la rotura de la probeta bajo tensiones normales y tangenciales, la carga se aplicaba en tres puntos con la entalla situada en una posición asimétrica, como muestran las Figuras 3 y 5 . Se hicieron un total de 36 ensayos, tres probetas por cada tamaño y orientación de los tendeles. Durante los ensayos se registró, además de la carga aplicada y el desplazamiento del pistón, el descenso del punto de aplicación de la carga, y la abertura de la boca de la entalla (CMOD). Para ello las probetas se instrumentaron con tres extensómetros, véanse las Figuras 3 y 5 para más detalles. developed. Two techniques were adopted to be able to observe cracks from the outset, before they were visible: a) specimens were coated with a thin layer of fluorescein (this substance changes colour when the crack first appears and the water contained inside the specimen leaks out), and b) the tip of the notch was observed under an optical microscope after the test.

\subsubsection{Three-point bending specimens}

This second type of test was conducted on the same load frame but with a bending device Specimen failure was attained under normal tensile and shear stresses by applying the load at three points with the notch positioned non-symmetrically, as shown in Figures 3 and 5. A total of 36 tests were conducted, with three specimens per size and bed joint orientation. In addition to the load applied and the actuator displacement, the descent of the load application point and crack mouth opening displacement (CMOD) were recorded during the test. The specimens were instrumented with three strain gauges for this purpose: see Figures 3 and 5 for further details.

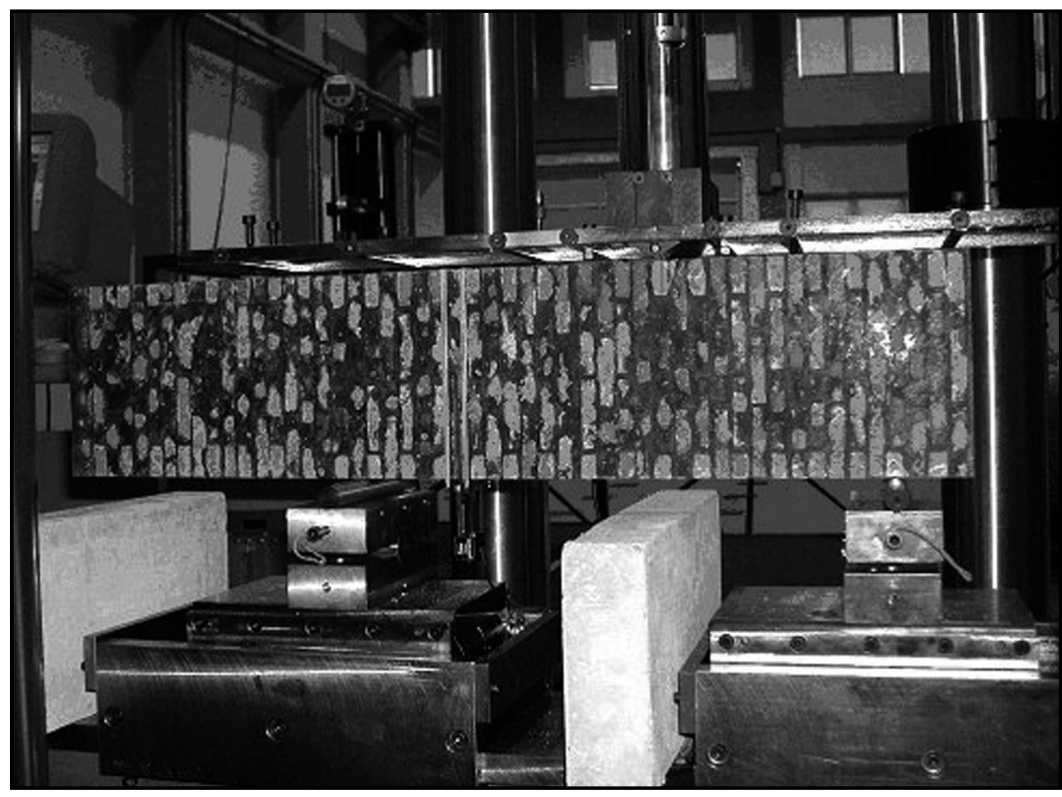

Figura 5. Probeta de flexión en tres puntos, con los tendeles a 90 grados, durante un ensayo.

Figure 5. Three-point bending specimen with 90-degree bed joints, during a test.

\section{RESULTADOS EXPERIMENTALES}

\subsection{Probetas con doble entalla}

Durante el ensayo la fluoresceína aplicada en las caras de las probetas permitió observar que las primeras fisuras en

\section{EXPERIMENTAL RESULTS}

\subsection{Double-edge notched specimens}

According to the colour changes in the fluorescein coating, the first cracks that appeared on the specimens 
aparecer fueron las fisuras de tracción y cortante en el lado no cargado de las probetas con doble entalla (véase Figura 6). Partiendo de la punta de las entallas todas las fisuras crecieron describiendo una curva hacia la parte libre de carga de la probeta. El crecimiento de estas fisuras continuó hasta que las compresiones en la mitad cargada de la probeta fueron suficientemente elevadas, momento en el cual comenzaron a aparecer las primeras fisuras típicas de rotura a compresión. Finalmente, la probeta colapsaba por compresión de la mitad cargada. during the test were tensile and shear stress cracks on the unloaded side of the double notched specimens (see Figure 6). All the cracks started at the notch tips, curving toward the unloaded part of the specimen. These cracks continued to grow until the compression on the loaded side of the specimen was high enough to generate the cracks characteristic of compression failure. Finally, the specimen collapsed under the compression stress on the loaded half.

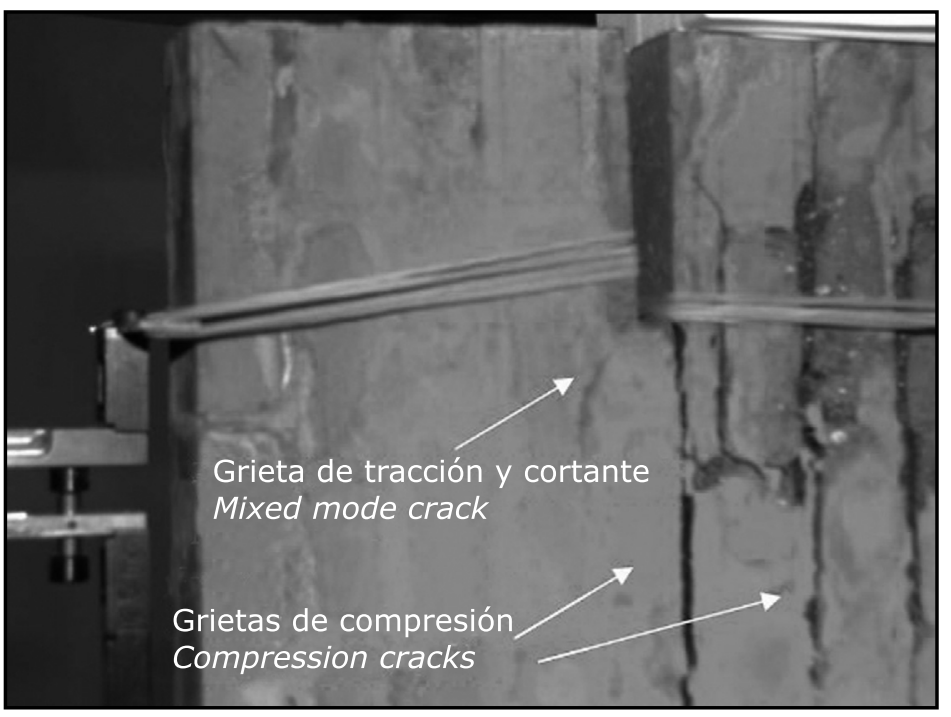

Figura 6. Trayectoria de la grieta de tracción y cortante en uno de los ensayos en el momento en que la probeta ha colapsado por compresión.

Figure 6. Tensile stress and shear crack during one of the tests as the specimen collapsed under compression stress.

La Figura 7 muestra los registros experimentales de carga frente al desplazamiento relativo de los puntos situados a la altura de la punta de las entallas sobre la cara vertical lateral de la mitad libre de carga de las probetas con doble entalla, para las tres orientaciones de los tendeles. En todos los casos las curvas muestran inicialmente un crecimiento lineal seguido de una rama curva, perdiendo esa linealidad, que experimenta desplazamientos decrecientes conforme aumenta la carga. La vuelta hacia atrás de las curvas se debe al inicio de la fisuración bajo tensiones normales y tangenciales y su posterior propagación desde las entallas, lo cual reduce la carga transmitida a través del ligamento entre la parte cargada y no cargada de la probeta. El pico de carga del ensayo está gobernado por el fallo a compresión de la mitad cargada.
Figure 7 plots the experimental load readings against the relative displacement of the points aligned with the tip of the notches on the vertical side of the unloaded half of the double notched specimens, for the three bed joint orientations. In all cases the curves grew first linearly and then bowed, and displacement declined with increasing loads. The reversal in the direction of the curve was due to the initiation of cracking under normal tensile and shear stress and subsequent propagation beginning at the notches, which reduced the load transmitted across the binder from the loaded to the unloaded part of the specimen. The peak test load was governed by compression failure in the loaded half. 

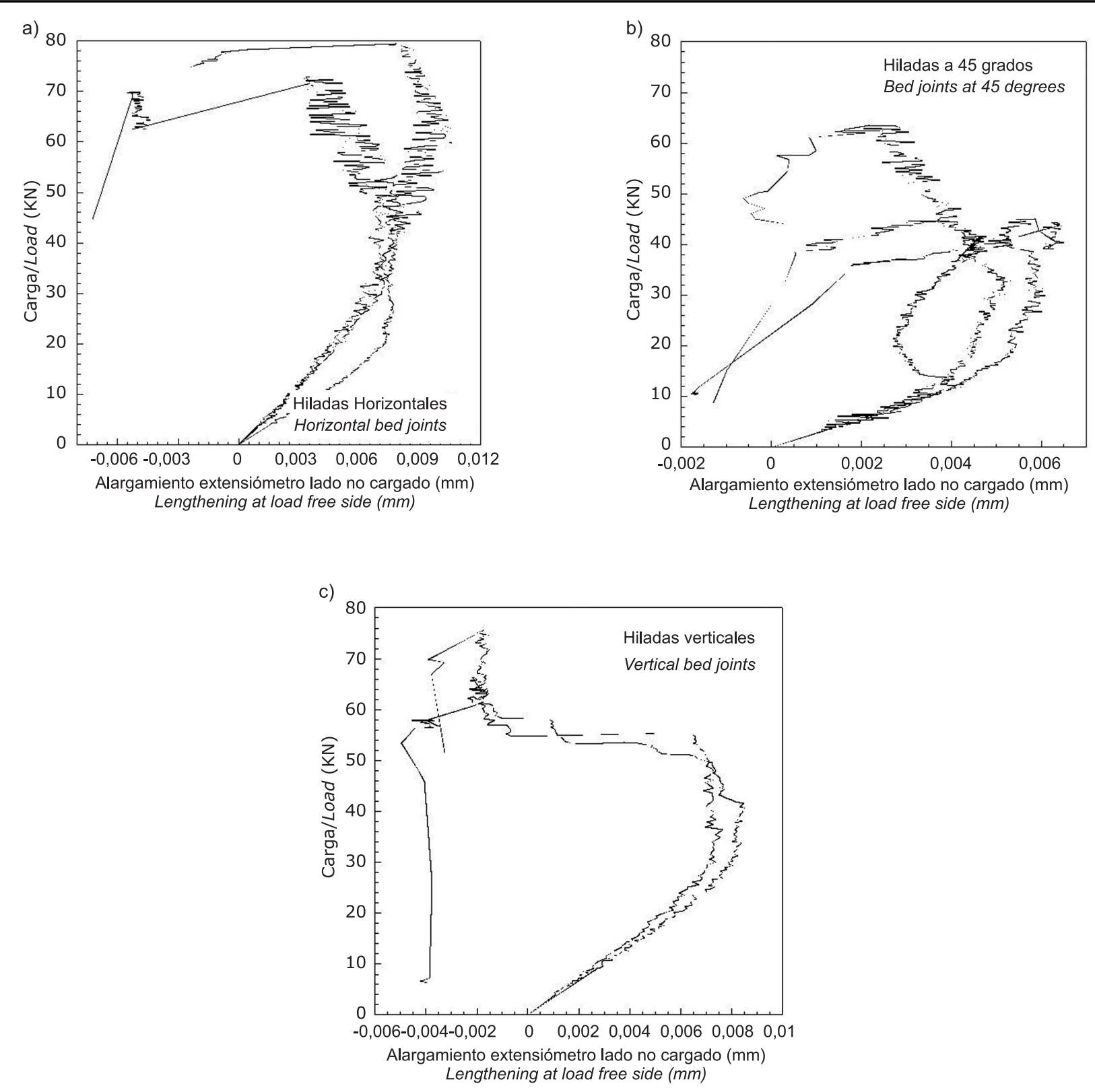

Figura 7. Resultados experimentales de la carga aplicada frente al alargamiento del extensómetro situado en la zona no comprimida: a), b) y c), para las probetas con las hiladas de ladrillos horizontales, a 45 grados y verticales, respectivamente.

Figure 7. Applied load versus elongation of the strain gauge positioned in the unloaded area:

a), b), and c): specimens with horizontal, 45-degree and vertical courses of brick, respectively.

\subsection{Probetas de flexión en tres puntos}

Durante el ensayo de los muros de fábrica a escala solicitados a flexión en tres puntos con la entalla asimétrica, se propagó una fisura desde la punta de la entalla hacia la zona de aplicación de la carga, mostrando distinto comportamiento para cada una de las orientaciones de las hiladas de ladrillo según la dirección de propagación de la grieta. La Figura 8 muestra estas distintas tendencias en las fisuras para las ocho orientaciones ensayadas:

\subsection{Three-point bending specimens}

During the test, the scale model masonry walls subjected to bending stress at three points positioned non-symmetrically around the notch cracked from the tip of the notch toward the area where the load was applied in directions that varied depending on the orientation of the courses of brick. Figure 8 shows these different cracking tendencies for the eight orientations tested: $0, \pm 30, \pm 45$, \pm 60 and 90 degrees The photographs in Figure 9 show 


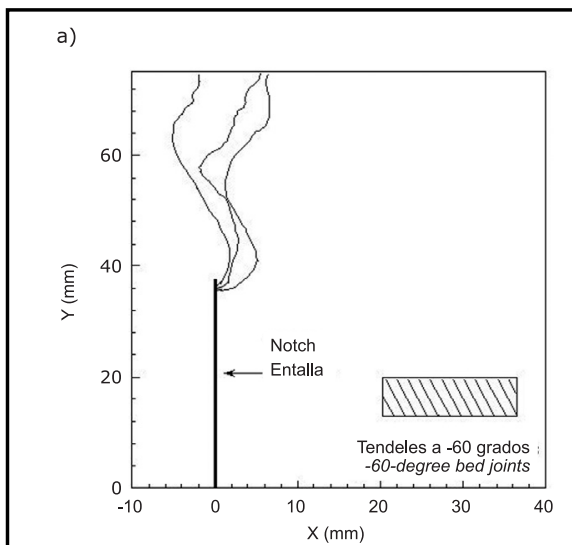

c)

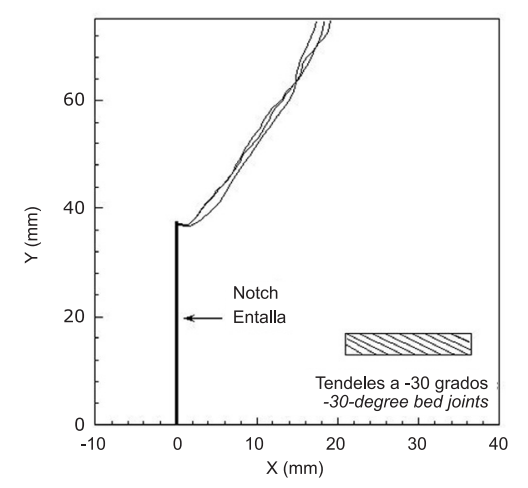

e)

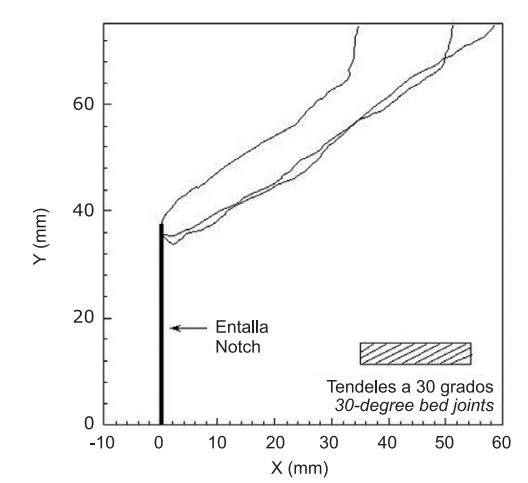

g)

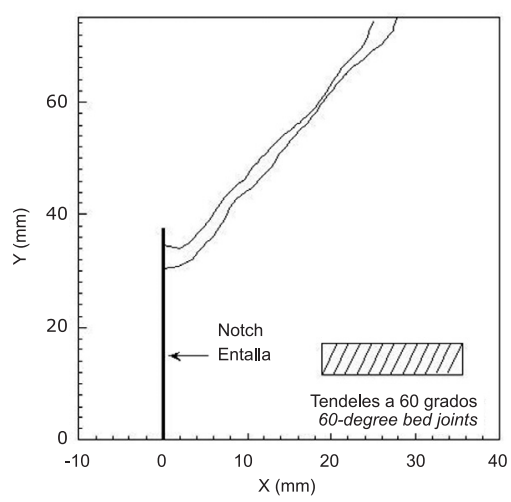

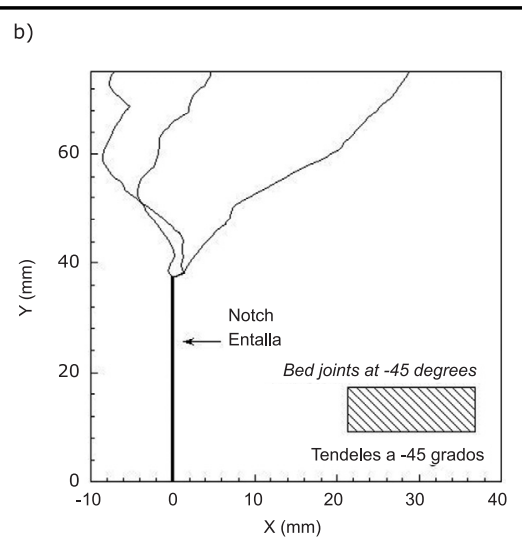

d)

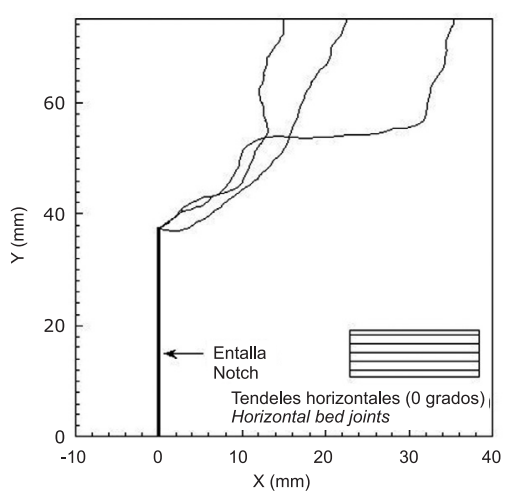

f)

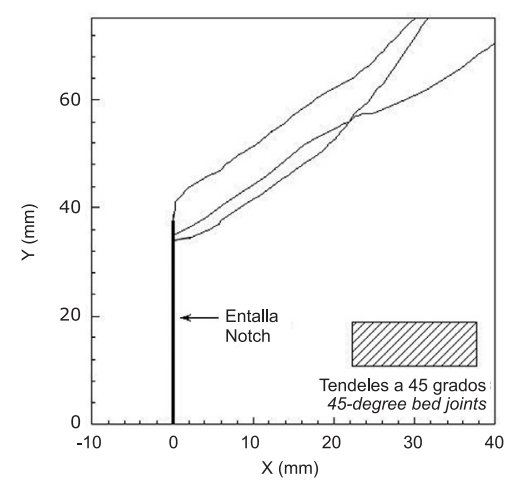

h)

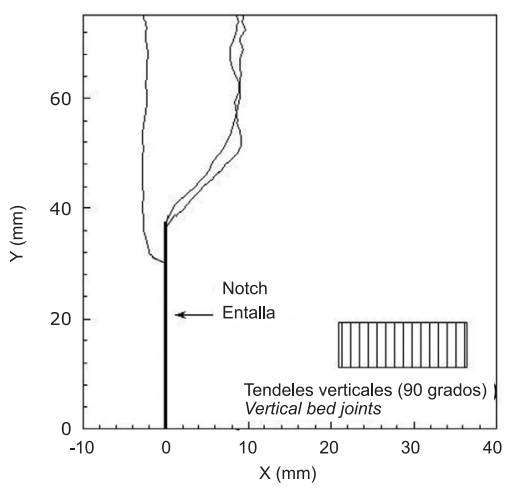

Figura 8. Trayectoria de las grietas en las probetas pequeñas $(D=75 \mathrm{~mm})$ para las orientaciones: $-60,-45,-30,0,30,45,60$ y 90 grados. Figure 8. Crack pathways in small $(D=75 \mathrm{~mm})$ specimens for the orientations: $-60,-45,-30,0,30,45,60$ and 90 degrees. 
$0, \pm 30, \pm 45, \pm 60$ y 90 grados. La Figura 9 muestra las fotos de la grietas en las probetas de tamaño grandes (D $=150 \mathrm{~mm}$ ) para cuatro orientaciones de los tendeles.

Casi todos los ensayos muestran la debilidad de la intercara ladrillo-mortero. Se observa como la propagación de las fisuras discurre según direcciones muy próximas a las inclinaciones de los tendeles para las orientaciones de 30 (Figura 8.e), 45 (Figuras 8.f y 9.c), 60 (Figura 8.g) y 90 grados (Figuras $8 . h$ y $9 . b$ ). En las probetas con los tendeles horizontales la grieta se propagó escalonadamente siguiendo las juntas ladrillo mortero (Figuras 8.d y 9.a). En el caso de la orientación a -45 grados (Figuras 8.b y 9.d), aunque la dispersión es mayor, la fisura discurrió principalmente inclinada hacia el punto de aplicación de la carga rompiendo ladrillos y mortero en una trayectoria bastante continua, ya que para esta orientación los planos de mayor debilidad de la fábrica se encontraban en una dirección prácticamente perpendicular. El tipo de fisuración fue parecido en las probetas con los tendeles a -60 y -30 grados.
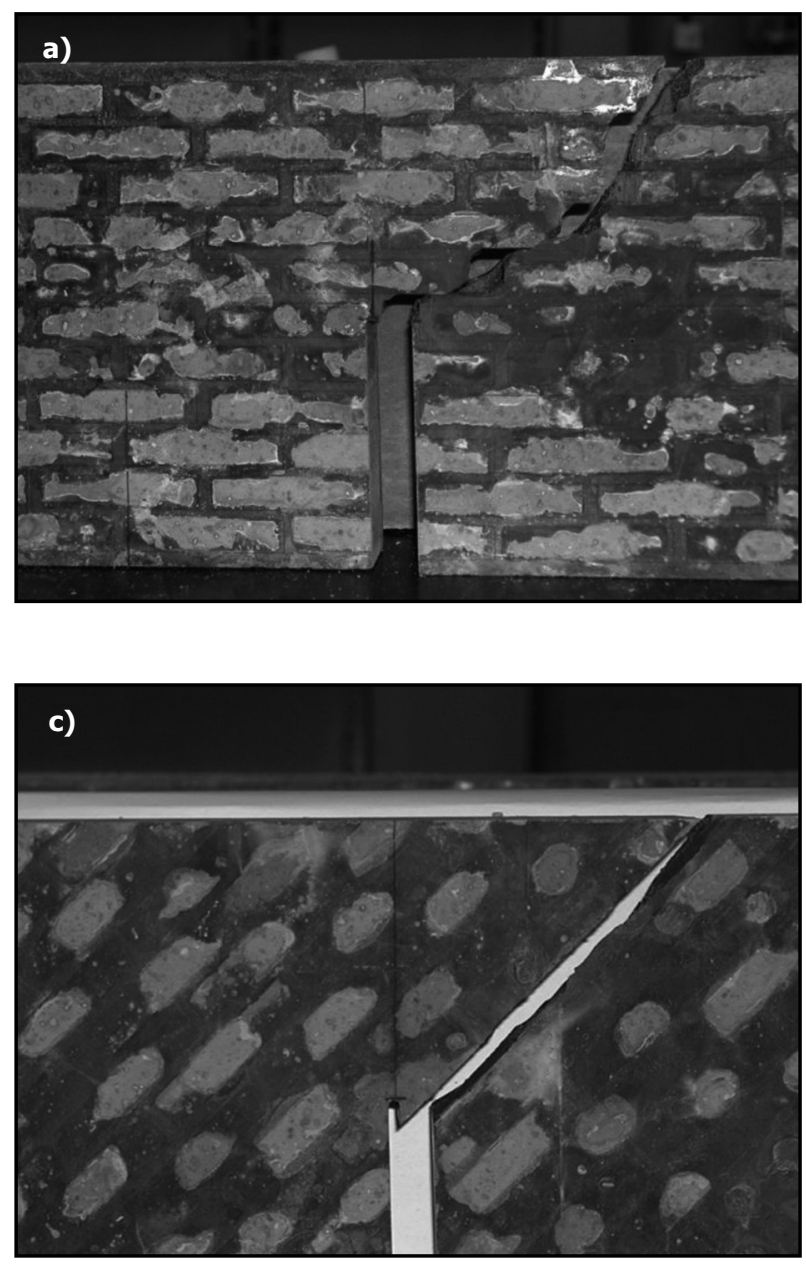

the cracks in the large specimens $(D=150 \mathrm{~mm})$ for four bed joint orientations.

Almost all the tests revealed the weakness of the brickmortar interface. Cracks were observed to grow in directions nearly parallel to the bed joints in the 30 (Figure 8.e), 45 (Figures 8.f and 9.c), 60 (Figure 8.g) and 90 (Figures 8.h and 9.b) degree orientations. In the specimens with horizontal bed joints the crack grew step-wise, along the brick-mortar joints (Figures 8.d and 9.a). While dispersion was greater in the -45 -degree orientation (Figures 8.b and 9.d), the cracks grew primarily on a slant toward the point where the load was applied, cutting across bricks and mortar in a fairly continuous path, for in this orientation the planes of greatest weakness were positioned nearly perpendicularly. Cracking was similar in specimens with -60- and-30-degree bed joints.
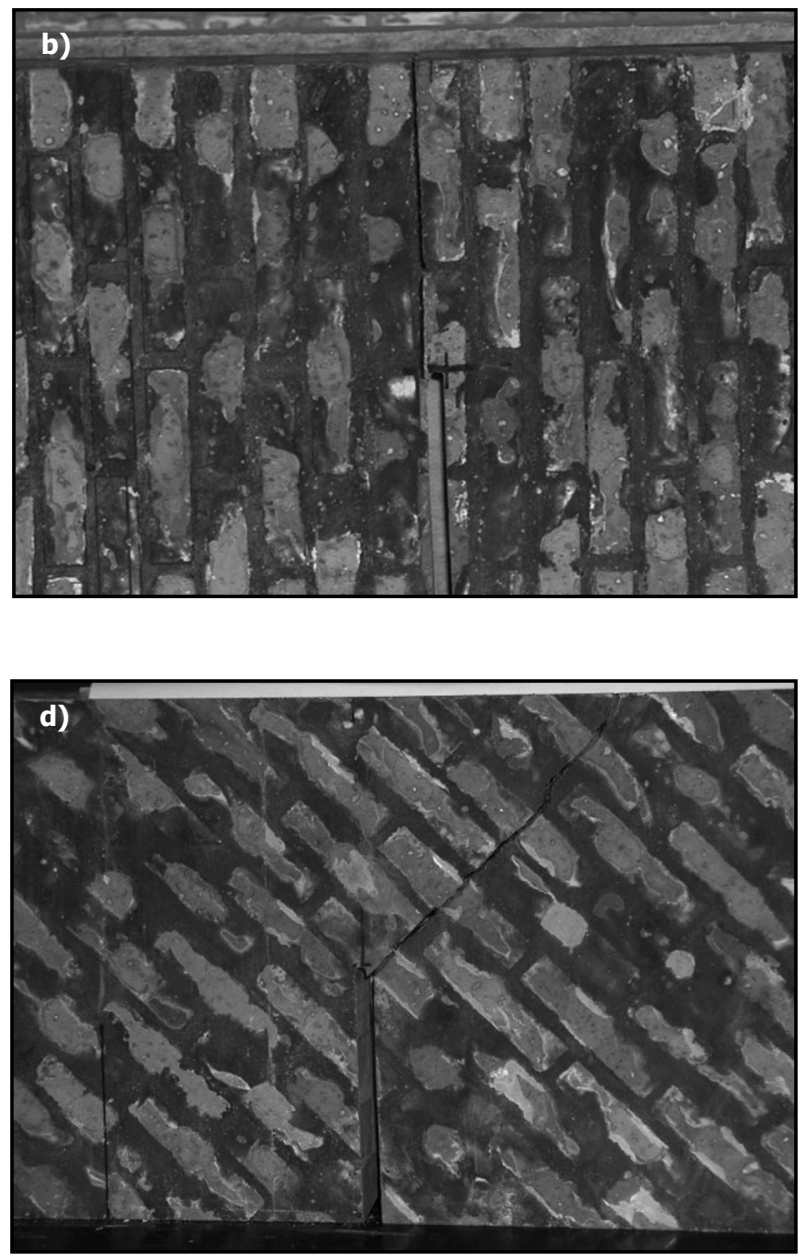

Figura 9. Grietas en las probetas de tamaño grande $(D=150 \mathrm{~mm})$ con los tendeles a:

a) 0 grados, b) 90 grados, c) 45 grados, y d) -45 grados.

Figure 9. Cracks in large specimens $(D=150 \mathrm{~mm})$ with bed joints at: a) 0 degrees, b) 90 degrees, c) 45 degrees and d)- 45 degrees. 

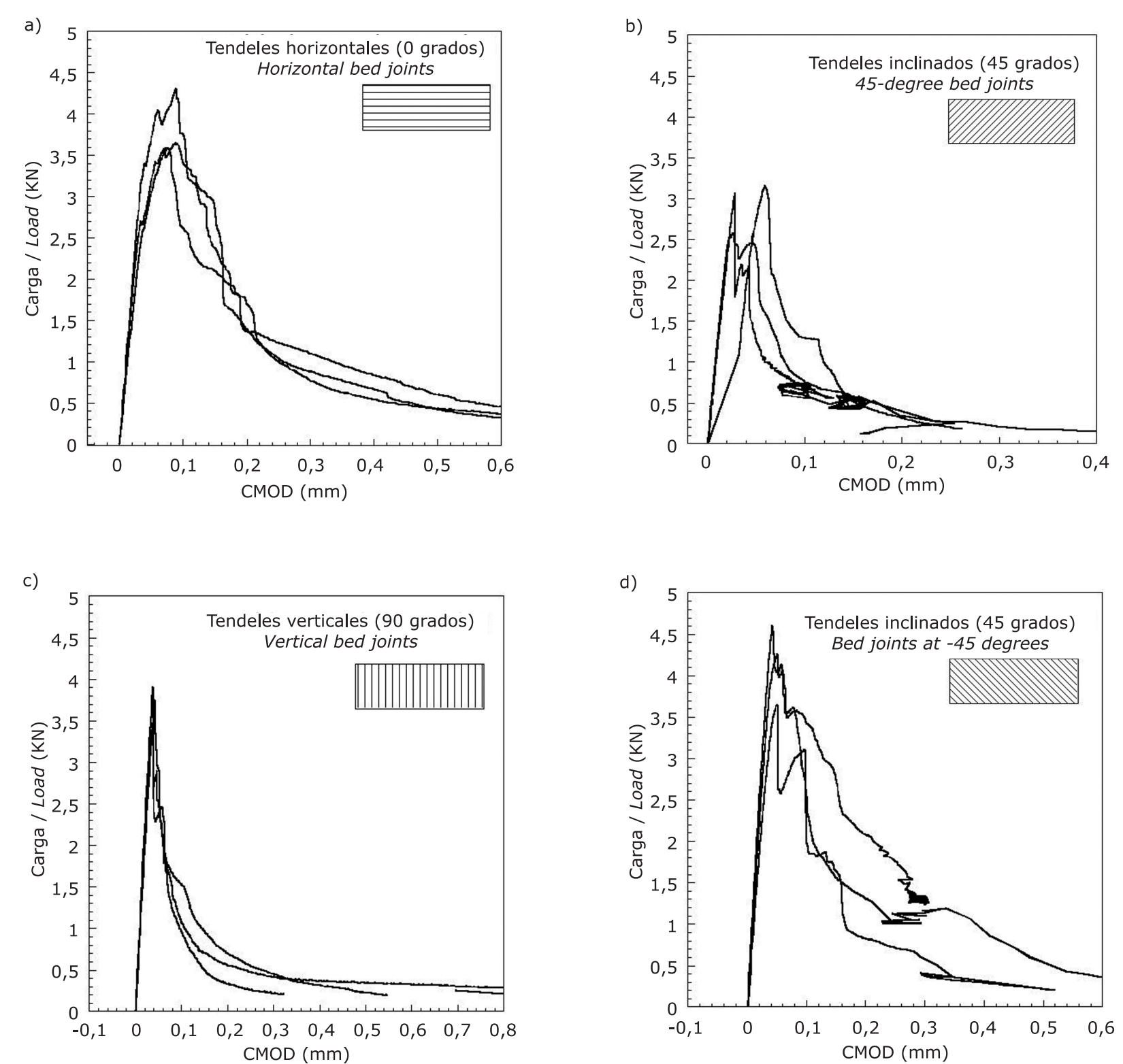

Figura 10. Registros experimentales de la carga aplicada frente al CMOD en las probetas grandes $(D=150 \mathrm{~mm})$ con distintas inclinaciones de los tendeles: a) 0 grados, b) 45 grados, c) 90 grados, y d) -45 grados.

Figure 10. Applied load versus CMOD in large $(D=150 \mathrm{~mm})$ specimens with bed joint orientations of: a) 0 degrees, b) 45 degrees, c) 90 degrees and d) -45 degrees.

La aparente irregularidad de los ladrillo mostrada en la Figura 9 no es tal, como ya se ha comentado, sino manchas superficiales de lechada de mortero producidas al confeccionar horizontalmente las probetas.

La Figura 10 muestra los registros experimentales cargaCMOD de las probetas de fábrica para el tamaño grande $(D=150 \mathrm{~mm}$ ) y las cuatro orientaciones de los tendeles. Se puede apreciar como, a pesar de la gran dispersión experimental que suele presentar la fábrica, los resulta-
As mentioned earlier, the apparent irregularity of the bricks in Figure 9 was actually due to grout stains on the surface that were the outcome of preparing the specimens in a horizontal position.

The experimental load readings for the large $(D=150$ $\mathrm{mm}$ ) masonry specimens and the four bed joint orientations are plotted against CMOD in Figure 10. Despite the wide experimental dispersion normally exhibited by 
dos obtenidos son repetitivos y muestran una dispersión experimental reducida.

La fábrica muestra la menor resistencia cuando la grieta se propaga por la junta entre ladrillo y mortero, que con la geometría de probeta ensayada corresponde a la orientación de 45 grados de los tendeles. La resistencia más alta corresponde a la propagación de la grieta cortando los ladrillos, que en nuestro caso corresponde a la orientación de -45 grados de los tendeles. Este resultado pone de manifiesto que las juntas entre ladrillo y mortero constituyen el elemento más débil de la fábrica frente a la rotura. Resultados similares se obtuvieron con las medidas de las probetas pequeñas, para las ocho orientaciones ensayadas.

Aunque sería muy conveniente comparar los resultados de los ensayos de fractura en modo mixto a escala con unos obtenidos a partir de ensayos a escala real no es posible por no existir en la literatura. Es de esperar una cierta influencia del efecto de tamaño en la hipotética comparación de resultados.

\section{CONCLUSIONES}

Dos han sido las tipologías de ensayo propuestas para el estudio de la fisuración de la fábrica de ladrillo bajo tensiones normales y tangenciales. En ambos procedimientos de ensayo se ha conseguido la rotura estable de paredes de ladrillo. Con ellos ha sido posible obtener resultados experimentales de rotura de fábrica bajo solicitaciones de tracción y cortante, que muestran una reducida dispersión experimental y pueden ser utilizados como referencia para contrastar la bondad de posibles modelos analíticos y numéricos para la fisuración de la fábrica bajo este tipo de solicitación.

En todos los ensayos se ha puesto de manifiesto la fuerte dependencia que tienen las propiedades mecánicas de la fábrica con la orientación de sus tendeles, que actúan como planos de debilidad. El fallo de la fábrica se produjo en un plano normal a la pared de fábrica, y en función de la orientación de las juntas horizontales, obedecía a uno de los siguientes mecanismos de rotura: fisuración a través de las juntas de mortero; o bien por fisuración combinada del ladrillo y el mortero. Las resistencias han sido mayores cuanto mayor ha sido el ángulo formado entre la dirección de la grieta y la de las juntas horizontales, caso en el que se producía el mecanismo de rotura mixto y la trayectoria de fisura cortaba bloques de ladrillo además de juntas de mortero. masonry, these results were repetitive with scant experimental dispersion.

Masonry strength was lowest when the crack grew along the joint between brick and mortar, which, under the specimen geometry tested here, concurred with the 45degree bed joint orientation. The highest strength was recorded for specimens that cracked across bricks, in this case when the bed joints were oriented on a -45-degree slant. These findings show that the joints between the brick and the mortar are the weakest element in masonry tested to failure. Similar results were obtained with the smaller specimens for the eight orientations tested.

While a comparison of the results of mixed mode failure tests for scale and full-size walls would have been recommendable, this was not possible for want of such data in the literature. Be it said in any case that size would be expected to have some effect in any such hypothetical comparison.

\section{CONCLUSIONS}

Two test methods were proposed to study cracking in brickwork masonry under normal and shear stresses. Stable wall failure was attained with both procedures, which yielded experimental tensile and shear stresses failure data for masonry that exhibited only minor experimental dispersion. These findings can be used as a reference to check the validity of possible analytical and numerical models for masonry cracking under this type of combined stresses.

All the tests showed the heavy dependence of the mechanical properties of masonry on the orientation of the bed joints, which behave like planes of weakness. The masonry failed on a plane perpendicular to the wall and, depending on the orientation of the horizontal joints, failure entailed one of the following mechanisms: cracking along the mortar joints or combined cracking of brick and mortar. The greater the angle formed between the direction of the crack and the direction of the horizontal joints, the greater was the strength recorded, i.e., in mixed failure the highest strength was observed when the path followed by the crack cut across bricks as well as mortar joints. 


\section{AGRADECIMIENTOS}

Los autores agradecen al Ministerio de Educación y Ciencia la ayuda económica concedida a través del proyecto BIA2005-09250-C03-02. Así mismo agradecen a la Junta de Comunidades de Castilla La Mancha la ayuda concedida a través del proyecto PAI06-0071-9403.

\section{ACKNOWLEDGEMENTS}

Funding for this research was provided by the Ministry of Education and Science under project BIA2005-09250CO3-02 and the Regional Government of Castilla-La Mancha under project PAI06-0071-9403.

\section{BIBLIOGRAFÍA / BIBLIOGRAPHY}

(1) Reyes, E.: Rotura de la fábrica de ladrillo bajo solicitaciones de tracción y cortante, Tesis Doctoral, Universidad de Castilla La Mancha (2004).

(2) Lorenço, P. J.: Computational strategies for masonry structures, Ph.D. Thesis, 211 pp., Delft, The Netherlans (1996).

(3) Lorenço, P. J., Rots, J., Blaauwendraad, J.: "Continuum model for masonry: parameter estimation and validation". ASCE J. Struct. Eng., Vol. 124 (1986), pp. 642-652.

(4) Jukes, P., Riddintong, J. R.: “The failure of brick triplet test specimens". Masonry International, Vol. 15, no1 (2001), pp. 30-33.

(5) Bosiljkov, V., Zarnic, R., Kralj, V., Pande, G.N.: Experimentally-Based Computational Modelling of Masonry, Computer Methods in Structural Masonry-4, pp. 103-110, E\&FN Spon, New York (1998).

(6) Rolando, A.: "Resistencia característica a compresión de una fábrica de ladrillo en función de la resistencia de sus componentes. Comprobación experimental de expresiones analíticas de la normativa europea". Mater. Construcc., vol. 56 (2006), pp. 91-98.

(7) Casati, M. J., Reyes, E., Gálvez, J. C.: "Resultados experimentales de la fractura en modo mixto de fábrica". Anales Mecánica de la Fractura, Vol. 19 (2002), pp. 399-404.

(8) Pluijm, R. van der: Out of plane bending of masonry behaviour and strength, Ph.D. Thesis, 259 pp., Delft, The Netherlands, (1999). (9) Guinea, G. V., Hussein, G., Elices, M., Planas, J.: "Micromechanical modelling of brick-masonry fracture". Cem. Concr. Res., Vol. 30 (2000), pp. 731 -737. http://dx.doi.org/10.1016/S0008-8846(00)00228-3

(10) Gálvez, J. C., Elices, M., Cendón, D. A.: "Fracture of double-edge notched specimens under compression loading". In Construction Materials: Theory and Application. pp. 95-105, Stuttgart: Ibidem-Verlag (1999).

(11) Gálvez, J. C., Cervenka, J., Saouma, V., Cendón, D. A.: "A discrete crack approach to normal/shear cracking of concrete". Cem. Concr. Res., Vol. 32 (2002), pp. 1567-1585. http://dx.doi.org/10.1016/S0008-8846(02)00825-6

(12) Page, A. W.: "The biaxial compressive strength of brick masonry", Proceedings of the Institute of Civil Engineers, Part 2, no 71 (1981), pp. 893-906.

(13) Page, A. W.: "The strength of brick masonry under biaxial compression-tension". Int. J. Masonry Construction, Vol. 3, № 1 (1983), pp. 26-31.

(14) RILEM 50-FCM Committee Fracture Mechanics of Concrete. "Determination of the fracture energy of mortar and concrete by means of three points bend tests of notched beams". Matériaux et Constructions, Vol. 18 (1986), pp. 285-290. 
